\title{
Darbepoietin-Alfa after High-Dose Melphalan and Autologous Hemopoietic Progenitor Cell in Multiple Myeloma Patients: A Pilot Study
}

\author{
Massimo Martino, Ida Callea, Tiziana Moscato, Antonella Pontari, Elisa Spiniello, Roberta Fedele
}

Department of Oncology and Hematology, Azienda Ospedaliera BMM, Reggio Calabria, Italy.

Email: maxmartino65@alice.it

Received August $3^{\text {rd }}, 2012$; revised September $4^{\text {th }}, 2012$; accepted September $12^{\text {th }}, 2012$

\begin{abstract}
We describe the effects of Darbepoietin-alfa (Darbe) administration in Multiple Myeloma (MM) after autologous hemopoietic progenitor cell transplantation (AHPCT). 26 MM patients undergoing AHPCT entered this study. 34 hemoglobin $(\mathrm{Hb})$-matched patients who had not received recombinant human erythropoietin (Epo) or Darbe and were treated with the same protocol were retrospectively selected for comparative data. Darbe (150 micro $g$ total dose/weekly) was initiating in four weeks after AHPCT, with the aim of achieving an $\mathrm{Hb}$ level of $\geq 11 \mathrm{~g} / \mathrm{dL}$. The time to response to Darbe therapy was longer in the patients with $\mathrm{Hb}<10 \mathrm{~g} / \mathrm{dL}(\mathrm{p}=0.05)$ and with endogenous Epo levels $\leq 50 \mathrm{mU} / \mathrm{ml}(\mathrm{p}=$ 0.0098). Hb level on day 60 and 90 after AHPCT, was faster for Darbe recipients (12.5, range $9.4-15.4$, vs 10.6, range $8.8-13.4 \mathrm{~g} / \mathrm{dL}, \mathrm{p}=0.0001$, and 13.5 , range $12.3-14.3$, vs 12 , range $9.8-14 \mathrm{~g} / \mathrm{dL}$, respectively, $\mathrm{p}=0.0001)$. The need for Red Blood Cells transfusion, included in the period of 30 - 90 days post-AHPCT was similar $(\mathrm{p}=\mathrm{ns})$. This study demonstrates the accelerating effect of Darbe on $\mathrm{Hb}$ increase in the setting evaluated and shows that this effect signifycantly depends on the endogenous Epo level at the start of treatment. The strategy of giving Darbe around 1 month after high-dose melphalan (HDM) doesn't reduce RBC transfusion requirement.
\end{abstract}

Keywords: Darbepoietin-Alfa; Anemia; Multiple Myeloma; Autologous Hematopoietic Progenitor Cell Transplantation

\section{Introduction}

Symptomatic anemia represents one of the major causes of morbidity in cancer patients and is associated with decreased functional capacities and compromised health related quality of life. In multiple myeloma (MM), anemia is most commonly due to chronic disease and bone marrow tumor infiltration and, in some cases, concomitant renal failure. Treatment with myelosuppressive chemotherapeutic agents further contributes to the anemia experienced by these patients [1]. Blood transfusion is generally the most common approach to treat anemia in patients receiving chemotherapy. The additional immunosuppression induced by transfusions increases the well-known risk of infection by blood products, not entirely overcome by the use of screening tests, and adversely influences disease control [2]. The beneficial effects of rHuEpo are well known and are not only related to the elimination of transfusion risks, but also to the improvement of functioning and health-related quality of life in anemic cancer patients [3-6]. It has been repeatedly demonstrated that anemia, reported in up to $70 \%$ of patients with MM [7], benefits of rHuEpo administration, either in terms of its prevention or its amelioration, with an overall reduction of Red Blood Cells (RBC) transfusion requirements and improvement in quality of life $[8,9]$. Looking at the bone marrow transplantation scenario, the administration of rHuEpo has been shown to be effective in reducing both the time to $\mathrm{RBC}$ transfusion independence and the number of RBC transfusions in the allogeneic setting [10-12]. Conversely, early rHuEpo administration in the autologous setting has failed to show any significant advantage [12-14]. High-dose chemotherapy with autologous hemopoietic progenitor cell transplantation (AHPCT) is being widely and increaseingly prescribed in patients affected by MM $[15,16]$. That this therapeutic option is incontestably of benefit for MM patients has been reinforced by the results of several trials, which definitively point out the superiority of high-dose over conventional treatment in terms of response rate, event free, and overall survival [17-20]. Darbepoietin-alpha (Darbe) is a unique erythropoietic protein with a longer half-life than rHuEpo, allowing less frequent dosing [21-23]. We designed a spontaneous nosponsorized case-control study to determine whether a 
strategy of giving Darbe around 1 month after high-dose melphalan (HDM) and AHPCT in MM patients could effectively improve the rate of haemoglobin $(\mathrm{Hb})$ rise and reduce $\mathrm{RBC}$ transfusion requirement in this setting.

\section{Material and Methods}

\subsection{Patients and Samples}

26 consecutive patients, 11 males 15 females, with de novo diagnosis of MM, stage II/III Durie-Salmon classification, were enrolled in the study protocol. The criteria for exclusion were: prior treatment for MM, another cancer, abnormal cardiac function (indicated by a systolic ejection fraction less than 50 percent), chronic respiratory disease (indicated by a vital capacity or carbon monoxide diffusing capacity less than 50 percent of predicted), abnormal liver function (indicated by a serum bilirubin level more than $2 \mathrm{mg}$ per decilitre [ $35 \mu \mathrm{mol}$ per litre] or an alanine aminotransferase or aspartate aminotransferase level more than four times the upper limit of normal) and psychiatric disease. All patients gave written informed consent to analyze their clinical data and the Ethics Committee of the local hospital approved this process. After the induction phase, patients were treated with Cyclophosphamide (CTX) chemotherapy
(3 - $4 \mathrm{gr} / \mathrm{mq})+\mathrm{G}-\mathrm{CSF}(10 \mu \mathrm{g} / \mathrm{kg} / \mathrm{d}$ for 10 days) to collect autologous hemopoietic progenitor cells (HPC). HDM $\left(200 \mathrm{mg} / \mathrm{m}^{2}\right)$ was used as a conditioning regimen for AHPCT. The day of stem cell re-infusion was termed day 0 . All patients received prophylaxis including oral ciprofloxacin $(500 \mathrm{mg}$ every $12 \mathrm{~h})$, acyclovir $(800 \mathrm{mg}$ every $8 \mathrm{~h}$ ), either fluconazole $(300 \mathrm{mg} / \mathrm{d})$ or itraconazole $(200 \mathrm{mg} / \mathrm{d})$ orally from day 5 until neutrophil recovery and trimethoprim/ sulphomethaxazole from days -8 to 0 . All patients received DMSO-depleted apheretic products in order to drastically reduce nausea, vomiting and cardiovascular symptoms [24]. Packed RBC and platelet concentrates (PC) were given when $\mathrm{Hb}<8 \mathrm{~g} / \mathrm{dL}$ and platelet count $<10 \times 109 / \mathrm{L}$, respectively, unless clinically indicated. Granulocyte-colony stimulating factor (G-CSF) was administered from day 3 until neutrophil engraftment. For comparison, 34 historical consecutive MM patients treated with the same chemotherapy regimen that had not received rHuEPO or Darbe after transplant in our department, were retrospectively analyzed and served as historical controls.

The main clinical characteristics and laboratory date, including White Blood Cells, $\mathrm{Hb}$, and Platelets, of these patients before and after Darbe administration are summarized on Table 1.

Table 1. Patients' characteristics.

\begin{tabular}{|c|c|c|c|}
\hline & Darbe Group & Control Group & $\mathbf{p}$ \\
\hline No. Patients & 26 & 34 & $n s$ \\
\hline Male vs Female & $11 / 15$ & $14 / 20$ & $n s$ \\
\hline Stage II/III Durie-Salmon & $2 / 24$ & $5 / 29$ & $n s$ \\
\hline Age, year, median (range) & $55.9(23.1-68.7)$ & $57.5(43-67)$ & $n s$ \\
\hline Disease status at transplant time & & & $n s$ \\
\hline Complete Remission $(\mathrm{CR})+$ near CR & 3 & 7 & \\
\hline Partial Remission & 22 & 27 & \\
\hline Progression & 1 & & \\
\hline N. CD34 + cells infused $\times 10 \mathrm{E} 6 / \mathrm{kg}$, median $($ range $)$ & $5(4-6)$ & $4.6(3-5.8)$ & $n s$ \\
\hline \multicolumn{4}{|l|}{ White Blood Cells $\times 10 \mathrm{E} 9 / \mathrm{L}$, median (range) } \\
\hline Basal value at transplant time & $4.5(2.8-8)$ & $4.3(2.2-7)$ & $n s$ \\
\hline 30 days post transplant & $3.9(2.2-6)$ & $3.8(1.9-7)$ & $n s$ \\
\hline \multicolumn{4}{|l|}{ Platelets $\times 10 \mathrm{E} 9 / \mathrm{L}$, median (range) } \\
\hline Basal value at transplant time & 190 & & \\
\hline Nadir during aplastic phase & $15(2-21)$ & $15(4-25)$ & $n s$ \\
\hline 30 days post transplant & $156(80-280)$ & $145(85-320)$ & $n s$ \\
\hline \multicolumn{4}{|l|}{ Hemoglobin value, gr/dL, median (range) } \\
\hline Basal value at transplant time & $11.7(8.2-16.3)$ & $11.7(9-15.8)$ & $n s$ \\
\hline Nadir during aplastic phase & $7.9(5.4-10.2)$ & $8.1(6.1-10.1)$ & $n s$ \\
\hline 30 days post transplant & $10.0(8.1-11.6)$ & $9.9(8.7-12.1)$ & $n s$ \\
\hline Serum creatinine $(\mathrm{mg} / \mathrm{dL})$ on day 30 & $0.8(0.5-1.2)$ & $0.9(0.6-1.4)$ & $n s$ \\
\hline
\end{tabular}




\subsection{Darbe Administration and Evaluation of Efficacy and Safety}

This was a spontaneous no-sponsorized case-control study and no collaboration with a drug company was been stated. Darbe (150 micro g total dose/weekly) was started four weeks post AHPCT, after all patients engrafted, platelet count was self-sustained $\geq 20 \times 10^{9} / \mathrm{L}$, and patients resolved their transplant-related toxicity including mucositis and diarrhoea, with the aim of achieving an $\mathrm{Hb}$ level of $\geq 11 \mathrm{~g} / \mathrm{dL}$. Complete blood counts, transferring saturation \%, serum ferritin level, serum sideraemia level and serum endogenous erythropoietin (Epo) level were measured at the time of Darbe start-up. For each patient, $\mathrm{Hb}$ was determined on the day before the administration of HDM, daily during the aplastic phase until engraftment, at study entry before the administration of Darbe, weekly until Darbe withdrawal and monthly for three months after AHPCT. Patients undergoing treatment with Darbe were defined as no responders if changes in $\mathrm{Hb}$ were less than $1 \mathrm{~g} / \mathrm{dL}$, partial responders if changes in $\mathrm{Hb}$ unrelated to transfusion were $\geq 1$ and $<2 \mathrm{~g} / \mathrm{dL}$, and complete responders if changes in $\mathrm{Hb}$ were $\geq 2 \mathrm{~g} / \mathrm{dL}$.

\subsection{Statistical Analysis}

The primary end point of this study was to evaluate the effect of Darbe after HDM and AHPCT on changes in $\mathrm{Hb}$ level from baseline and on the cumulative transfusion rate, calculated as the number of RBC units transfused in each single patient during the subsequent 3 months after transplant, and the capacity of patients to maintain an $\mathrm{Hb}$ $\geq 11 \mathrm{gr} / \mathrm{dL}$ during the time of observation.

The secondary end point was to evaluate the safety (i.e., risk of venous thromboembolism [VTE] and allcause or treatment-associated mobility and death). Safety was assessed by incidence and severity of adverse events by treatment group. All toxicities related to Epo were graded according to the National Cancer Institute Com -mon Toxicity Criteria.

The results were additionally compared with the data obtained in a historical group of patients with $\mathrm{MM}$ who were treated with HDM and AHPCT but did not receive an erythropoiesis-stimulating protein. Data were analyzed by descriptive statistical methods. Nonparametric correlations and differences between groups were calculated by the Mann-Whitney U test, by Fisher's exact test, Pearson chi-square, and by Mantel-Haenszel estimate with $95 \% \mathrm{CI}$, as appropriate. The time to reach the $\mathrm{Hb}$ target was performed using the Kaplan-Meier method. Statistical significance of associations between individual variables and the time to reach the $\mathrm{Hb}$ target was calculated by the log-rank test. All statistical calculations were performed using the statistical package SPSS for Win- dows, release 11.5, 2002 software (SPSS UK, Working, Surrey, United Kingdom). A value of $p \leq 0.05$ was considered significant for all statistical calculations.

\section{Results}

There were no differences between the two groups in terms of gender, age, disease stage, amount of CD34+ cells infused and disease status at transplant and since cases were matched for $\mathrm{Hb}$ levels before HDM.

The median $\mathrm{Hb}$ levels at baseline were similar between the two groups, with a median value of $11.8 \mathrm{~g} / \mathrm{dL}$ (interquartile range 8.2 - 14.3) in the Darbe Group versus $11.7 \mathrm{~g} / \mathrm{dL}$ (interquartile range $9-13.8$ ) in the Control Group. The median nadir of $\mathrm{Hb}$ after AHPCT was similar between the two groups $(7.9 \mathrm{~g} / \mathrm{dL}$-interquartile range $5.4-10.2$ in the Darbe Group versus $8.1 \mathrm{~g} / \mathrm{dL}$-interquartile range $6.1-10.1$ in the Control Group). No significant differences in terms of myeloid and platelet engraftment and number of days with severe neutropenia were observed. Moreover, the days of hospitalization (14, range 12 - 20, Darbe versus 14, range $11-29$, controls), the number of febrile episodes ( $48 \%$ in the Darbe group versus $50 \%$ in the control group), the rate of mucositis (68\% Darbe versus $66 \%$ controls), and were equally distributed between the two groups.

In the Darbe group, the median time to start the drug was 30 days (range 25 - 35) post AHPCT. The day of Darbe start-up, the median $\mathrm{Hb}$ value was $9.5 \mathrm{~g} / \mathrm{dL}$ (range $\mathrm{Hb} 8.1-9.9 \mathrm{~g} / \mathrm{dL}$ ). All patients achieved a haematopoietic response $(\mathrm{Hb}$ concentration of $\geq 11 \mathrm{gr} / \mathrm{dL}$ in the absence of any RBC transfusions during the subsequent 3 months after transplant). A significant slower response to Darbe therapy was experienced by those patients starting with $\mathrm{Hb}$ levels $<10 \mathrm{~g} / \mathrm{dL}$ [4 weeks (CI 3 - 5 weeks) versus 5 weeks (CI 3 - 7 weeks), p =0.05]. Furthermore, 100\% of patients maintained an $\mathrm{Hb} \geq 11 \mathrm{gr} / \mathrm{dL}$ for the time of observation (3 months). An exploratory analysis revealed that baseline serum endogenous Epo concentration influenced the magnitude of the effect of Darbe. The $\mathrm{Hb}$ target was reached faster for patients with baseline endogenous Epo levels $\leq 50 \mathrm{mU} / \mathrm{mL}$ [4 weeks (CI 3 - 5 weeks)] compared with endogenous Epo group $>50$ $\mathrm{mU} / \mathrm{mL}$ [6 weeks (CI 5 - 7 weeks), $\mathrm{p}=0.0098$ ]. Thus, Darbe demonstrated clinically important improvements in response rate, regardless of baseline endogenous Epo level (Figure 1).

In univariate analysis, response to Darbe therapy failed to be significantly associated with basal serum ferritin level, basal serum sideraemia levels and transferrin saturation \% level. No correlation was found between status of disease before the transplant and the time to reach the $\mathrm{Hb}$ target.

Compared to historical controls, the mean $\mathrm{Hb}$ corre- 
ction valuated 45, 60, 75 and 90 days after AHPCT, was faster for Darbe recipients $(10.9 \pm 0.9$ vs $9.9 \pm 1, \mathrm{p}=$ $0.009 ; 12.3 \pm 1.5$ vs $10.7 \pm 1.2, \mathrm{p}=0.001 ; 13 \pm 1$ vs 11.4 $\pm 1.2, \mathrm{p}=0.001 ; 13.5 \pm 0.5$ vs $11.9 \pm 1.1, \mathrm{p}=0.001$, respectively) (Figure 2).

The median number of RBC transfusions (unit) during aplastic phase was 1 (range 0 - 5) in Darbe group and 0.5 (range 0 - 4) in the control group (p=ns). RBC transfusion requirements included in the period of 30-90 days post-AHPCT was similar (no patients in Darbe group vs $3 / 36$ in Control group, respectively, $p=n s$ ).

The administration of Darbe was not associated with related severe side effects (i.e., thromboembolic complications). Mild hypertension was reported in only one patient, fever in two patients (WHO 1 and WHO 2, respectively) and nausea in one patient (WHO 2).

\section{Discussion and Conclusions}

This is a spontaneous trial, addressing the vexing problem of anemia of delayed $\mathrm{RBC}$ recovery after stem cells transplant. The administration of $\mathrm{rHuEpo}$ has been shown to be effective in reducing both the time to RBC transfu-

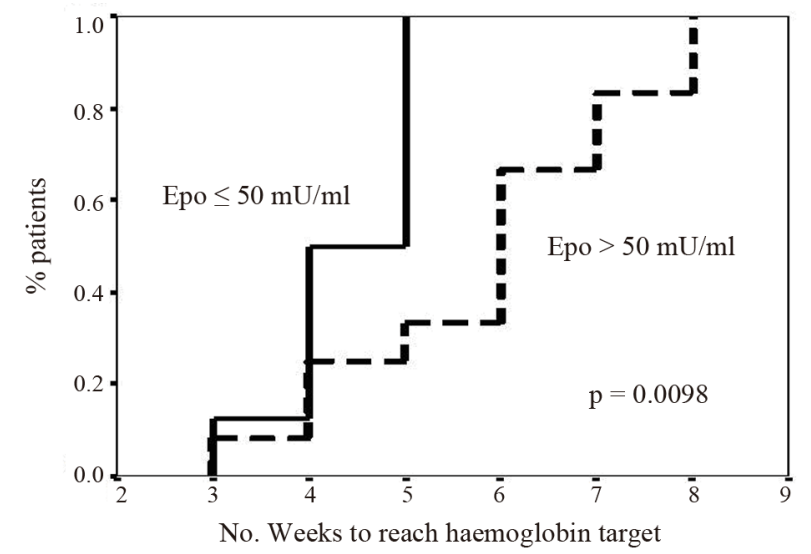

Figure 1. Response to Darbepoietin-alfa therapy correlated with serum endogenous Erythropoietin (Epo) level.

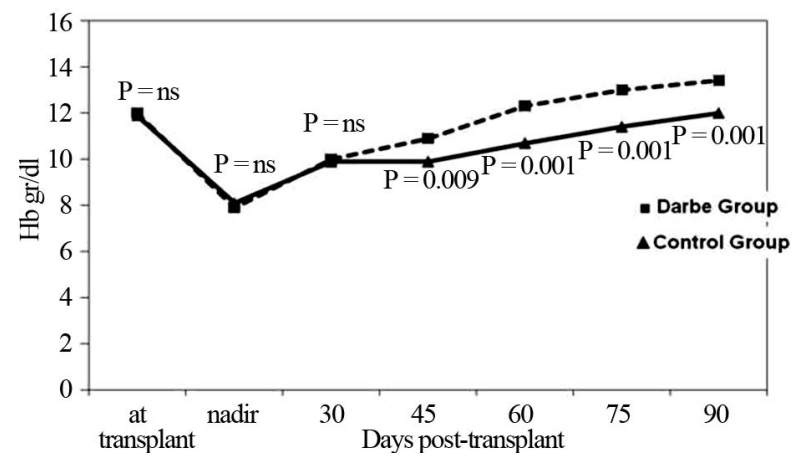

Figure 2. Mean haemoglobin ( $\mathrm{Hb})$ levels in the Control and Darbepoietin-alfa (Darbe) group after autologous hemopoietic progenitor cell transplant. sion independence and the number of RBC transfusions in the allogeneic setting [10-12]. Conversely, early rHuEpo administration in the autologous setting has failed to show any significant advantage [12-14]. On the other side, Ponchio et al. [25] described that in patients undergoing high dose sequential chemotherapy for breast cancer, rHuEpo given before therapy can substantially reduce the use of allogeneic blood products. Baron et al. [26] showed that a short course of rHuEpo therapy therapy given between first and second HDM in MM patients allows second peripheral blood stem cell transplantation without RBC transfusion. As our point out, in the post transplant allogeneic setting, Epo seems to be effective, probably because the engrafted bone marrow is "healthy" as opposed to the autologous setting where the patient's own re-engrafted bone marrow is not so "healthy".

The timeliness of response is an important characteristic of anemia therapy. To investigate this, we evaluated the achievement of a target $\mathrm{Hb}$ threshold and subsequent maintenance of a $\mathrm{Hb}$ range $(11-13 \mathrm{~g} / \mathrm{dL})$ based on recommendations of the EORTC and ASH/ASCO evidence-based guidelines as well as on the approved label instructions for darbepoetin alfa and Epoetin alfa [27,28].

Although our work has the limitations of no randomization with a relatively small group of patients treated, the results show a more rapid increase in $\mathrm{Hb}$ level in patients treated with Darbe than in matched group of control patients. Moreover, $100 \%$ of patients achieved the $\mathrm{Hb}$ target level and maintained an $\mathrm{Hb} \geq 11 \mathrm{gr} / \mathrm{dL}$ for the time of observation. This clinical practice has not resulted in a reduction of transfusion support, and the study failed this crucial objective. Probably, a more appropriate parameter for evaluating the benefit of treatment would have been the measurement of quality of life (QoL), but this was not the subject of the study. It is known that QoL significantly improves with increases in $\mathrm{Hb}$ level, particularly between $11 \mathrm{~g} / \mathrm{dL}$ and $13 \mathrm{~g} / \mathrm{dL}$ [29].

The rationale of the study to start treatment with an erythropoiesis-stimulating protein after the recovery of the bone marrow and the return of Epo to an appropriate level for the degree of anemia in patients with AHPCT has already been successfully evaluated in other studies, including a prospective randomized trial using recombinant human Epo once a week [30]. The new aspect in the present study may be to show that the same effect can be achieved by using Darbe. No published data are available to describe the real-world community practice usage patterns and relative clinical effectiveness of Darbe after AHPCT. Darbe is a unique erythropoietic protein with an approximately threefold longer half-life than rHuEpo, allowing less frequent dosing. While Darbe has a longer half-life, it also has a lower affinity Epo-receptor binding coefficient and this essentially nets out, making the two molecules the same in clinical practice. In fact, the more 
patients are studied for their Epo half-lives, the more we realize that the patient type and the chemotherapy type can drastically alter the measurements between these two molecules [31].

Other studies have started the Epo at the time of transplant (on day 1 after HPC infusion and continuing for 1 - 2 months or until erythroid engraftment and carried it out 4 - 6 weeks) not showing a difference from placebo [32-41]. In this study Darbe started 4 weeks after transplant when the autologous marrow is recovering and, therefore, much more likely to respond to the exogenous Epo stimulation. The patients then may be in the anemia of chronic disease model (inadequate Epo for degree of anemia), or not (the bone marrow "failure" types and Epo levels high), leading further to the observation in this paper that those with the lower Epo levels were more likely to respond. This is the real crux of this study and taken together, this paper demonstrates the accelerating effect of Darbe on $\mathrm{Hb}$ increase in the setting evaluated and shows that this effect significantly depends on the endogenous Epo level at the start of treatment. The exploratory analysis is discussed that Epo concentrations were predictive of response, where the patients with Epo levels less than 50 have the greater response rates. This is a very important feature of this trial, which continues to make the point that anemia of chronic disease patients, i.e., those whose Epo levels do not raise enough in response to the developing anemia, have the best response to exogenous Epo therapy.

Elevated serum Epo levels are described after highdose chemotherapy without significantly changes in $\mathrm{Hb}$ [42-44]. The peak Epo levels are showed around 7 days after stem cells infusion, at the time of the nadir of RBC production. Contemporaneously with the hematological recovery, Epo levels grow again, and the duration of this period inversely correlates with the time of engraftment [45]. Furthermore, endogenous Epo remains appropriate for the degree of anemia in patients after AHPCT $[42,43]$. Baron et al. [46] showed that after AHPCT endogenous Epo levels decreased slowly and remained adequate for the degree of anemia until day 21, when levels became inappropriately low. Epo values returned to appropriate levels around day 100 after the transplant.

Prospective clinical trials are an essential tool for evaluating darbepoietin alfa versus epoietin alfa in the setting of AHPCT, but our results.

\section{Acknowledgements}

We are really grateful to all technicians for technical assistance in hematology laboratory.

\section{REFERENCES}

[1] T. J. Littlewood, "Erythropoietin for the Treatment of
Anaemia Associated with Hematological Malignancy," Hematological Oncology, Vol. 19, No. 1, 2001, pp. 19-30. doi: $10.1002 /$ hon. 663

[2] A. Osterborg, "Recombinant Human Erythropoietin (rHu EPO) Therapy in Patients with Cancer-Related Anaemia: What Have We Learned?" Medical Oncology, Vol. 15, Suppl. 1, 1998, pp. S47-S49.

[3] G. D. Demetri, M. Kris, J. Wade, L. Degos and D. Cella, "Quality-of-Life Benefit in Chemotherapy Patients Treated with Epoetin Alfa Is Independent of Disease Response or Tumor type: Results from a Prospective Community Oncology Study," Journal of Clinical Oncology, Vol. 16, No. 10, 1998, pp. 3412-3425.

[4] T. J. Littlewood, E. Bajetta, J. W. Nortier, E. Vercammen, B. Rapoport and Epoetin Alfa Study Group, "Effects of Epoetin Alfa on Hematologic Parameters and Quality of Life in Cancer Patients Receiving Non-Platinum Chemotherapy: Results of a Randomised, Double-Blind, Placebo-Controlled Trial," Journal of Clinical Oncology, Vol. 19, No. 11, 2001, pp. 2865-2874.

[5] J. L. Gabrilove, C. S. Cleeland, R. B. Livingston, B. Sarokhan, E. Winer and L. H. Einhorn, "Clinical Evaluation of Once-Weekly Dosing of Epoetin Alfa in Chemotherapy Patients: Improvements in Hemoglobin and Quality of Life Are Similar to Three-Times-Weekly Dosing," Journal of Clinical Oncology, Vol. 19, No. 11, 2001, pp. 2875-2882.

[6] J. Glaspy, R. Bukowski, D. Steinberg, C. Taylor, S. Tchekmedyian and S. Vadhan-Raj, "Impact of Therapy with Epoetin Alfa on Clinical Outcomes in Patients with Nonmyeloid Malignancies during Cancer Chemotherapy in Community Oncology Practice. Procrit Study Group," Journal of Clinical Oncology, Vol. 15, No. 3, 1997, pp. 1218-1234.

[7] R. A. Kyle, "Multiple Myeloma: Review of 869 Cases," Mayo Clinic Proceedings, Vol. 50, No. 1, 1975, pp. 29-40.

[8] F. Dammacco, G. Castaldi and S. Rödjer, "Efficacy of Epoetin Alfa in the Treatment of Anemia of Multiple Myeloma," British Journal of Haematology, Vol. 113, No. 1, 2001, pp. 172-179. doi:10.1046/j.1365-2141.2001.02715.x

[9] A. Osterborg, Y. Brandberg, V. Molostova, G. Iosava, K. Abdulkadyrov, M. Hedenus, D. Messinger and Epoetin Beta Hematology Study Group, "Randomized, DoubleBlind, Placebo-Controlled Trial of Recombinant Human Erythropoietin, Epoetin Beta, in Hematologic Malignancies," Journal of Clinical Oncology, Vol. 20, No. 10, 2002, pp. 2486-2494. doi:10.1200/JCO.2002.08.131

[10] J. L. Steegmann, J. López, M. J. Otero, M. L. Lamana, R. de la Cámara, M. Berberana, A. Díaz and J. M. Fernández-Rañada, "Erythropoietin Treatment in Allogeneic BMT Accelerates Erythroid Reconstitution: Results of a Prospective Controlled Randomised Trial," Bone Marrow Transplantation, Vol. 10, No. 6, 1992, pp. 541-546.

[11] S. Klaesson, O. Ringdén, P. Ljungman, B. Lönnqvist and L. Wennberg, "Reduced Blood Transfusions Requirement after Allogeneic Bone Marrow Transplantation: Results of a Randomised, Double-Bind Study with High-Dose 
Erythropoietin," Bone Marrow Transplantation, Vol. 13, No. 4, 1994, pp. 397-402.

[12] C. B. Mille and H. M. Lazarus, "Erythropoietin in Stem Cell Transplantation," Bone Marrow Transplantation, Vol. 27, No. 10, 2001, pp. 1011-1016. doi:10.1038/sj.bmt.1703022

[13] D. H. Henry, "Epoetin Alfa and High-Dose Chemotherapy," Seminars in Oncology, Vol. 25, No. 3, Suppl. 7, 1998, pp. 54-57.

[14] M. Danova and S. Ferreri, "Anemia and Epoetin Alfa in High-Dose Chemotherapy Programs for Breast Cancer Patients," Seminars in Oncology, Vol. 29, No. 3, Suppl. 8, 2002, pp. 21-25.

[15] B. Barlogie, S. Jagannath, K. R. Desikan, S. Mattox, D. Vesole, D. Siegel, G. Tricot, N. Munshi, A. Fassas, S. Singhal, J. Mehta, E. Anaissie, D. Dhodapkar, S. Naucke, J. Cromer, J. Sawyer, J. Epstein, D. Spoon, D. Ayers, B. Cheson and J. Crowley, "Total Therapy with Tandem Transplants for Newly Diagnosed Multiple Myeloma," Blood, Vol. 93, No. 1, 1999, pp. 55-65.

[16] M. Tribalto, S. Amadori, L. Cudillo, T. Caravita, G. Del Poeta, G. Meloni, G. Avvisati, M. T. Petrucci, A. Pulsoni, G. Leone, S. Sica, M. Martelli, A. Tabilio, G. Fioritoni, I. Majolino and F. Mandelli, "Autologous Peripheral Blood Stem Cell Transplantation as First Line Treatment of Multiple Myeloma: An Italian Multicenter Study," Haematologica, Vol. 85, No. 1, 2000, pp. 52-58.

[17] M. Attal, J. L. Harousseau, A. M. Stoppa, J. J. Sotto, J. G. Fuzibet, J. F. Rossi, P. Casassus, H. Maisonneuve, T. Facon, N. Ifrah, C. Payen and R. Bataille, "A Prospective, Randomized Trial of Autologous Bone Marrow Transplantation and Chemotherapy in Multiple Myeloma. The Intergroupe Français du Myélome," The New England Journal of Medicine, Vol. 335, No. 2, 1996, pp. 91-97. doi:10.1056/NEJM199607113350204

[18] P. Moreau, T. Facon, M. Attal, C. Hulin, M. Michallet, F. Maloisel, J.-J. Sotto, F. Guilhot, G. Marit, C. Doyen, J. Jaubert, J.-G. Fuzibet, S. François, L. Benboubker, M. Monconduit, L. Voillat, M. Macro, C. Berthou, V. Dorvaux, B. Pignon, B. Rio, T. Matthes, P. Casassus, D. Caillot, N. Najman, B. Grosbois, R. Bataille and J.-L. Harousseau for the Intergroupe Francophone du Myélome, "Comparison of $200 \mathrm{mg} / \mathrm{m}^{2}$ Melphalan and 8 Gy Total Body Irradiation Plus $140 \mathrm{mg} / \mathrm{m}^{2}$ Melphalan as Conditioning Regimens for Peripheral Blood Stem Cell Transplantation in Patients with Newly Diagnosed Multiple Myeloma: Final Analysis of the Intergroupe Francophone du Myelome 9502 Randomized Trial," Blood, Vol. 99, No. 3, 2002, pp. 731-735. doi:10.1182/blood.V99.3.731

[19] B. Barlogie, S. Jagannath, D. H. Vesole, S. Naucke, B. Cheson, S. Mattox, D. Bracy, S. Salmon, J. Jacobson, J. Crowley and G. Tricot, "Superiority of Tandem Autologous Transplantation over Standard Therapy for Previously Untreated Multiple Myeloma," Blood, Vol. 89, No. 3, 1997, pp. 789-793.

[20] M. Attal, J.-L. Harousseau, T. Facon, F. Guilhot, C. Doyen, J.-G. Fuzibet, M. Monconduit, C. Hulin, D. Caillot, R. Bouabdallah, L. Voillat, J.-J. Sotto, B. Grosbois and R. Bataille for the InterGroupe Francophone du
Myélome, "Single versus Double Autologous Stem-Cell Transplantation for Multiple Myeloma," The New England Journal of Medicine, Vol. 349, No. 26, 2003, pp. 24952502. doi:10.1056/NEJMoa032290

[21] A. Osterborg, "New Erythropoietic Proteins: Rationale and Clinical Data," Seminars in Oncology, Vol. 31, No. 3 , Suppl. 8, 2004, pp. 12-18. doi:10.1053/j.seminoncol.2004.04.005

[22] M. Bloomfield, G. Jaresko, J. Zarek and N. Dozier, "Guidelines for Using Darbepoetin Alfa in Patients with Chemotherapy-Induced Anemia," Pharmacotherapy, Vol. 23, No. 12, Pt. 2, 2003, pp. 110S-118S. doi:10.1592/phco.23.16.110S.31970

[23] J. Patton, T. Reeves and J. Wallace, "Effectiveness of Darbepoetin Alfa versus Epoetin Alfa in Patients with Chemotherapy-Induced Anemia Treated in Clinical Practice," Oncologist, Vol. 9, No. 4, 2004, pp. 451-458.

[24] M. Martino, F. Morabito, G. Messina, G. Irrera, G. Pucci and P. Iacopino, "Fractionated Infusions of Cryopreserved Stem Cells May Prevent DMSO-Induced Major Cardiac Complications in Graft Recipients," Haematologica, Vol. 81, No. 1, 1996, pp. 59-61.

[25] L. Ponchio, A. Zambelli, A. De Stefano, F. S. R. D. Cuna, C. Perotti and P. Pedrazzoli, "Transfusion Requirement Can Be Abolished by Epoietin-A and Autologous Platelet Predeposit in Patients Receiving High Dose Chemotherapy with Stem Cell Support," Haematologica, Vol. 85, No. 2, 2000, pp. 219-220.

[26] F. Baron, P. Frère, G. Fillet and Y. Beguin, "Tandem High-Dose Therapy (HDT) for Multiple Myeloma: Recombinant Human Erythropoietin Therapy Given between First and Second HDT Allows Second Peripheral Blood Stem Cell Transplantation without Red Blood Cell Transfusion," British Journal of Haematology, Vol. 123 No. 1, 2003, pp. 103-105. doi:10.1046/j.1365-2141.2003.04556.x

[27] J. D. Rizzo, M. R. Somerfield, K. L. Hagerty, J. Seidenfeld, J. Bohlius, C. L. Bennett, D. F. Cella, B. Djulbegovic, M. J. Goode, A. A. Jakubowski, M. U. Rarick, D. H. Regan, A. E. Lichtin, American Society of Clinical Oncology and American Society of Hematology, "Use of Epoetin and Darbepoetin in Patients with Cancer: 2007 American Society of Clinical Oncology/American Society of Hematology Clinical Practice Guideline Update," Journal of Clinical Oncology, Vol. 26, No. 1, 2008, pp. 132-149. doi:10.1200/JCO.2007.14.3396

[28] C. Bokemeyer, M. S. Aapro, A. Courdi, J. Foubert, H. A. Link, A. Osterborg, L. Repetto and P. Soubeyran, "EORTC Guidelines for the Use of Erythropoietic Proteins in Anaemic Patients with Cancer," European Journal of Cancer, Vol. 40, 2004, pp. 2201-2216. doi:10.1016/j.ejca.2004.07.015

[29] J. Crawford, D. Cella, C. S. Cleeland, P. Y. Cremieux, G. D. Demetri, B. J. Sarokhan, M. B. Slavin and J. A. Glaspy, "Relationship between Changes in Hemoglobin Level and Quality of Life during Chemotherapy in Anemic Cancer Patients Receiving Epoetin Alfa Therapy," Cancer, Vol. 95, No. 4, 2002, pp. 888-895. doi:10.1002/cncr.10763 
[30] G. Vanstraelen, F. Baron, P. Frère, K. Hafraoui, G. Fillet and Y. Beguin, "Efficacy of Recombinant Human Erythropoietin Therapy Started One Month after Autologous Peripheral Blood Stem Cell Transplantation," Haematologica, Vol. 90, No. 9, 2005, pp. 1269-1270.

[31] J. Glaspy, D. Henry, R. Patel, S. Tchekmedyian, S. Applebaum, D. Berdeaux, R. Lloyd, R. Berg, M. Austin, G. Rossi and Darbepoetin Alfa 20010162 Study Group, "Effects of Chemotherapy on Endogenous Erythropoietin Levels and the Pharmacokinetics and Erythropoietic Response of Darbepoetin Alfa: A Randomised Clinical Trial of Synchronous versus Asynchronous Dosing of Darbepoetin Alfa," European Journal of Cancer, Vol. 41, No. 8, 2005, pp. 1140-1149. doi:10.1016/j.ejca.2005.01.021

[32] A. Pedrazzini, "Erythropoietin and GM-CSF following Autologous Bone Marrow Transplantation," European Journal of Cancer, Vol. 29A, Suppl. 2, 1993, pp. S15-S17. doi:10.1016/S0959-8049(05)80284-9

[33] R. Pene, F. R Appelbaum, L. Fisher, K. Lilleby, J. Nemunaitis, R. Storb and C. D. Buckner, "Use of Granulocyte-Macrophage Colony-Stimulating Factor and Erythropoietin in Combination after Autologous Marrow Transplantation," Bone Marrow Transplantation, Vol. 11, No. 3, 1993, pp. 219-222.

[34] L. J. Ayash, A. Elias, M. Hunt, G. Demetri, C. Wheeler, I. Tepler, G. Schwartz, R. Mazanet, E. Reich, M. McCauley, et al., "Recombinant Human Erythropoietin for the Treatment of the Anaemia Associated with Autologous Bone Marrow Transplantation," British Journal of Haematology, Vol. 87, No. 1, 1994, pp. 153-161. doi:10.1111/j.1365-2141.1994.tb04886.x

[35] H. Link, M. A. Boogaerts, A. A. Fauser, S. Slavin, J. Reiffers, N. C. Gorin, A. M. Carella, F. Mandelli, S. Burdach, A. Ferrant, et al., "A Controlled Trial of Recombinant Human Erythropoietin after Bone Marrow Transplantation," Blood, Vol. 84, No. 10, 1994, pp. 33273335.

[36] F. Locatelli, M. Zecca, P. Pedrazzoli, L. Prete, S. Quaglini, P. Comoli, P. De Stefano, Y. Beguin, G. Robustelli della Cuna, F. Severi, "Use of Recombinant Human Erythropoietin after Bone Marrow Transplantation in Pediatric Patients with Acute Leukemia: Effect on Erythroid Repopulation in Autologous versus Allogeneic Transplants," Bone Marrow Transplantation, Vol. 13, No. 4, 1994, pp. 403-410.

[37] N. J. Chao, J. R. Schriber, G. D. Long, R. S. Negrin, M. Catolico, B. W. Brown, L. Miller and K. G. Blume, "A Randomized Study of Erythropoietin and Granulocyte Colony-Stimulating Factor (G-CSF) versus Placebo and G-CSF for Patients with Hodgkin's and Non-Hodgkin's Lymphoma Undergoing Autologous Bone Marrow Transplantation," Blood, Vol. 83, No. 10, 1994, pp. 2823-2828.

[38] C. B. Miller and S. Mills, "Erythropoietin after Bone
Marrow Transplantation," Hematology/Oncology Clinics of North America, Vol. 8, No. 5, 1994, pp. 975-992.

[39] L. Pierelli, G. Scambia, G. Menichella, G. D’Onofrio, G. Salerno, P. B. Panici, M. L. Foddai, M. Vittori, M. Lai, M. Ciarli, G. Puglia, S. Mancuso and B. Bizzi, "The Combination of Erythropoietin and Granulocyte Colony-Stimulating Factor Increases the Rate of Haemopoietic Recovery with Clinical Benefit after Peripheral Blood Progenitor Cell Transplantation," British Journal of Haematology, Vol. 92, No. 2, 1996, pp. 287-294. doi:10.1046/j.1365-2141.1996.d01-1502.x

[40] A. M. Vannucchi, A. Bosi, A. Ieri, S. Guidi, R. Saccardi, L. Lombardini, S. Linari, D. Laszlo, G. Longo and P. Rossi-Ferrini, "Combination Therapy with G-CSF and Erythropoietin after Autologous Bone Marrow Transplantation for Lymphoid Malignancies: A Randomized Trial," Bone Marrow Transplantation, Vol. 17, No. 4, 1996, pp. 527-531.

[41] P. Benedetti, L. Pierelli, G. Scambia, M. L. Foddai, M. G. Salerno, G. Menichella, M. Vittori, F. Maneschi, U. Caracussi, R. Serafini, G. Leone and S. Mancuso, "HighDose Carboplatin, Etoposide and Melphalan (CEM) with Peripheral Blood Progenitor Cell Support as Late Intensification for High-Risk Cancer: Non-Haematological, Haematological Toxicities and Role of Growth Factor Administration," British Journal of Cancer, Vol. 75, No. 8, 1997, pp. 1205-1212. doi:10.1038/bjc.1997.206

[42] Y. Beguin, G. K. Clemons, R. Oris and G. Fillet, "Circulating Erythropoietin Levels after Bone Marrow Transplantation: Inappropriate Response to Anemia in Allogeneic Transplants," Blood, Vol. 77, No. 4, 1991, pp. 868873.

[43] Y. Beguin, R. Oris and G. Fillet, "Dynamics of Erythropoietic Recovery Following Bone Marrow Transplantation: Role of Marrow Proliferative Capacity and Erythropoietin Production in Autologous versus Allogeneic Transplants," Bone Marrow Transplantation, Vol. 11, No. 4, 1993, pp. 285-292.

[44] F. Baron, G. Fillet and Y. Beguin, "Erythropoiesis after Nonmyeloablative Stem-Cell Transplantation Is Not Impaired by Inadequate Erythropoietin Production as Observed after Conventional Allogeneic Transplantation," Transplantation, Vol. 74, No. 12, 2002, pp. 1692-1696. doi:10.1097/00007890-200212270-00008

[45] Y. Beguin, F. Baron and G. Fillet, "Influence of Marrow Activity on Serum Erythropoietin Levels after Autologous Hematopoietic Stem Cell Transplantation," Haematologica, Vol. 83, No. 12, 1998, pp. 1076-1081.

[46] F. Baron, P. Frère, G. Fillet and Y. Beguin, "Recombinant Human Erythropoietin Therapy Is Very Effective after an Autologous Peripheral Blood Stem Cell Transplant When Started Soon after Engraftment," Clinical Cancer Research, Vol. 15, No. 88, 2003, pp. 5566-5572. 